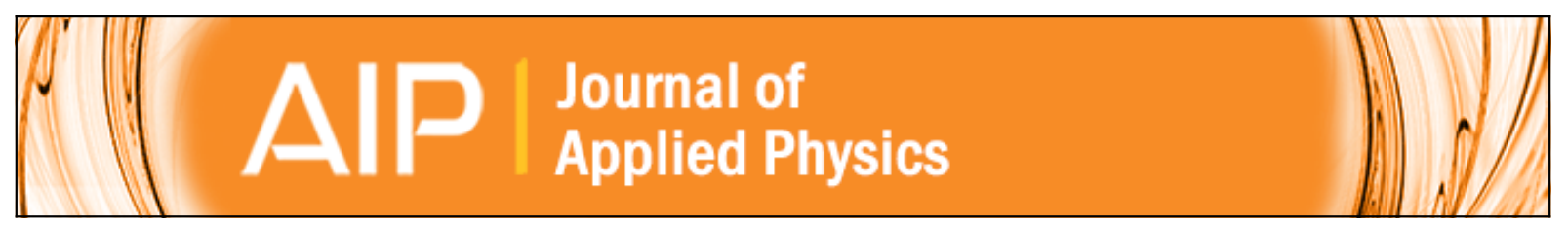

\title{
Amorphous silicon oxide window layers for high-efficiency silicon heterojunction solar cells
}

Johannes Peter Seif, Antoine Descoeudres, Miha Filipi, Franc Smole, Marko Topi, Zachary Charles Holman, Stefaan De Wolf, and Christophe Ballif

Citation: Journal of Applied Physics 115, 024502 (2014); doi: 10.1063/1.4861404

View online: http://dx.doi.org/10.1063/1.4861404

View Table of Contents: http://scitation.aip.org/content/aip/journal/jap/115/2?ver=pdfcov

Published by the AIP Publishing

\section{Articles you may be interested in}

Optimized amorphous silicon oxide buffer layers for silicon heterojunction solar cells with microcrystalline silicon oxide contact layers

J. Appl. Phys. 113, 134501 (2013); 10.1063/1.4798603

Enhancing the efficiency of SnS solar cells via band-offset engineering with a zinc oxysulfide buffer layer Appl. Phys. Lett. 102, 053901 (2013); 10.1063/1.4789855

Analysis of sub-stoichiometric hydrogenated silicon oxide films for surface passivation of crystalline silicon solar cells

J. Appl. Phys. 112, 054905 (2012); 10.1063/1.4749415

Window layer with $\mathrm{p}$ doped silicon oxide for high $\mathrm{V}$ oc thin-film silicon n-i-p solar cells

J. Appl. Phys. 110, 124511 (2011); 10.1063/1.3669389

Towards a high efficiency amorphous silicon solar cell using molybdenum oxide as a window layer instead of conventional $p$-type amorphous silicon carbide

Appl. Phys. Lett. 99, 063504 (2011); 10.1063/1.3624591

\section{A|P $\left.\right|_{\text {Applied Physics }} ^{\text {Journal of }}$}

Journal of Applied Physics is pleased to announce André Anders as its new Editor-in-Chief 


\title{
Amorphous silicon oxide window layers for high-efficiency silicon heterojunction solar cells
}

\author{
Johannes Peter Seif, ${ }^{1, a)}$ Antoine Descoeudres, ${ }^{1, b)}$ Miha Filipič, ${ }^{2}$ Franc Smole, ${ }^{2}$ \\ Marko Topič ${ }^{2}$ Zachary Charles Holman, ${ }^{1, \mathrm{c})}$ Stefaan De Wolf, ${ }^{1}$ and Christophe Ballif ${ }^{1}$ \\ ${ }^{1}$ Institute of Microengineering (IMT), Photovoltaics and Thin-Film Electronics Laboratory, Ecole \\ Polytechnique Fédérale de Lausanne (EPFL), Rue de la Maladière 71b, CH-2002 Neuchâtel, Switzerland \\ ${ }^{2}$ Faculty of Electrical Engineering, University of Ljubljana, Tržaška 25, SI-1000 Ljubljana, Slovenia
}

(Received 23 September 2013; accepted 20 December 2013; published online 10 January 2014)

In amorphous/crystalline silicon heterojunction solar cells, optical losses can be mitigated by replacing the amorphous silicon films by wider bandgap amorphous silicon oxide layers. In this article, we use stacks of intrinsic amorphous silicon and amorphous silicon oxide as front intrinsic buffer layers and show that this increases the short-circuit current density by up to $0.43 \mathrm{~mA} / \mathrm{cm}^{2}$ due to less reflection and a higher transparency at short wavelengths. Additionally, high open-circuit voltages can be maintained, thanks to good interface passivation. However, we find that the gain in current is more than offset by losses in fill factor. Aided by device simulations, we link these losses to impeded carrier collection fundamentally caused by the increased valence band offset at the amorphous/crystalline interface. Despite this, carrier extraction can be improved by raising the temperature; we find that cells with amorphous silicon oxide window layers show an even lower temperature coefficient than reference heterojunction solar cells $\left(-0.1 \% /{ }^{\circ} \mathrm{C}\right.$ relative drop in efficiency, compared to $-0.3 \% /{ }^{\circ} \mathrm{C}$ ). Hence, even though cells with oxide layers do not outperform cells with the standard design at room temperature, at higher temperatures-which are closer to the real working conditions encountered in the field-they show superior performance in both experiment and simulation. (C) 2014 AIP Publishing LLC.

[http://dx.doi.org/10.1063/1.4861404]

\section{INTRODUCTION}

An important prerequisite for reaching high efficiencies in crystalline silicon solar cells is good surface passivation of the wafer. This enables high voltages at open circuit $\left(V_{\mathrm{oc}}\right)$ but also at the maximum power point, leading to high fill factors $(F F){ }^{1}$ For silicon heterojunction (SHJ) solar cells, intrinsic hydrogenated amorphous silicon $(i$ a-Si:H) buffer layers have been proven to offer outstanding passivation. ${ }^{2-5}$ In this cell design, shown schematically in Fig. 1, doped ( $n$ or $p$ ) a-Si:H overlayers are used to form junctions as electron and hole collectors, ${ }^{6,7}$ allowing the fabrication of nearly recombination-free contacts..$^{2-68-11}$ However, the high absorption coefficient and relatively narrow quasi-direct bandgap of a-Si:H $(\sim 1.7 \mathrm{eV})$, combined with its high defect density, give rise to significant parasitic losses in the ultraviolet and visible range of the solar light spectrum, as most of the photogenerated carriers in these films recombine before they can be collected. ${ }^{11-14}$ For typical SHJ cells, we found earlier that all light absorbed in the $p$-layer is lost, whereas one-third of the light absorbed in the intrinsic passivation layer contributes to the generation of current. ${ }^{15}$ Parasitic absorption also occurs in the front transparent conductive oxide (TCO) layer, the presence of which is required

\footnotetext{
a)Phone: +41 (0)2169542 64. Fax: +41 (0)21 69542 01. Electronic mail: johannes.seif@epfl.ch.

b) Present address: Swiss Center for Electronics and Microtechnology (CSEM), Rue Jaquet-Droz 1, CH-2002 Neuchâtel, Switzerland.

${ }^{c}$ Present address: School of Electrical, Computer \& Energy Engineering, Arizona State University, Tempe, AZ, USA.
}

for efficient current extraction due to the low lateral conductivity of the doped a-Si:H layers. We currently lose only $0.3 \mathrm{~mA} / \mathrm{cm}^{2}$ in the front TCO for wavelengths below $600 \mathrm{~nm}$, which is much less than the $2 \mathrm{~mA} / \mathrm{cm}^{2}$ lost in our standard front a-Si:H layers. ${ }^{15}$

A possible approach to reduce parasitic absorption also in the a-Si:H layers is to increase the threshold energy for absorption by using a material with a wider bandgap. Widebandgap doped amorphous silicon oxide layers with nanocrystallites $\left(\mathrm{nc}^{-} \mathrm{SiO}_{\mathrm{x}}: \mathrm{H}\right)$ are used in thin-film silicon tandem solar cells as window layers and intermediate reflectors ${ }^{16,17}$ showing the potential for improved light management. In SHJ devices, intrinsic amorphous silicon oxide $\left(\mathrm{a}-\mathrm{SiO}_{\mathrm{x}}: \mathrm{H}\right)$ as well as doped $\mathrm{nc}-\mathrm{SiO}_{\mathrm{x}}: \mathrm{H}$ layers were tested as passivation and charge-carrier collection layers, respectively, and promising results were reported on $p$-type ${ }^{18-20}$ and $n$-type $\mathrm{t}^{21}$

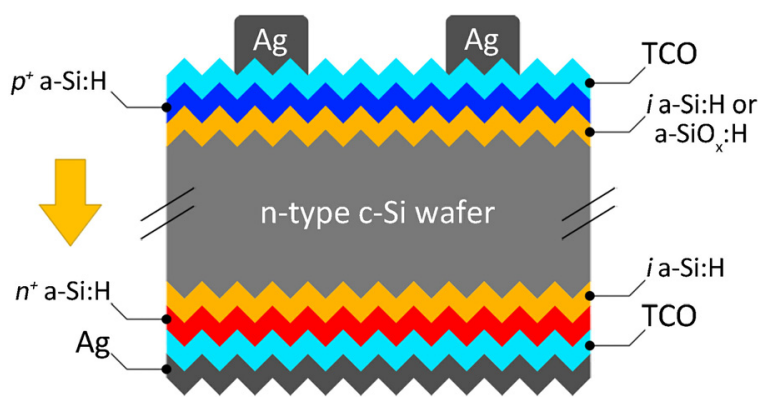

FIG. 1. Silicon heterojunction solar cell structure investigated in this work. The arrow indicates the direction of the incident light. 
crystalline silicon wafers. However, a direct comparison of such layers to state-of-the-art a-Si:H films has been lacking so far, making an assessment of their true potential difficult.

In the present work, we make this comparison and focus on introducing $i$ a-SiO ${ }_{\mathrm{x}}: \mathrm{H}$ in the place of standard $i \mathrm{a}-\mathrm{Si}: \mathrm{H}$ to assess its potential as a buffer and window layer at the front. From the literature it is known that the doping efficiency of $\mathrm{a}-\mathrm{Si}: \mathrm{H}$ is reduced by the introduction of oxygen. ${ }^{22}$ Hence, to avoid possibly ambiguous results, in this work, we concentrate on the buffer layer only and present studies on how the oxygen content and thickness of the layer influence device performance. We assess the wafer passivation properties of $\mathrm{a}-\mathrm{SiO}_{\mathrm{x}}: \mathrm{H}$ layers, their optical properties and their influence on carrier collection.

\section{EXPERIMENTS}

The device results discussed in this work were obtained for $2 \times 2 \mathrm{~cm}^{2}$ cells (with 3 cells per wafer) with the following structure (see Fig. 1): screen-printed $\mathrm{Ag}$ front grid/ indium tin oxide $\left(\mathrm{In}_{2} \mathrm{O}_{3}: \mathrm{Sn}, \mathrm{ITO}\right) 70 \mathrm{~nm} / p^{+}$a-Si:H $10 \mathrm{~nm} /$ $i$ a-Si:H or $i$ a-SiO $\mathrm{Si}_{\mathrm{x}}: \mathrm{H}(5 \mathrm{~nm}$ unless otherwise indicated)/ textured float-zone $n$ c-Si $230 \mu \mathrm{m} / i$ a-Si:H $5 \mathrm{~nm} / n^{+}$a-Si:H $10 \mathrm{~nm} / \mathrm{ITO} 150-200 \mathrm{~nm} / \mathrm{Ag}$ full rear metallization. For fabrication, first the wafers were textured using potassium hydroxide, then they were cleaned by wet-chemical means, and finally they were dipped in a hydrofluoric acid solution (5\%) for chemical oxide removal just before layer deposition. All a-Si:H layers were deposited at $200^{\circ} \mathrm{C}$ in a medium-sized (electrode size: $15 \times 16 \mathrm{~cm}^{2}$ ) plasma-enhanced chemical vapor deposition (PECVD) cluster tool (INDEOtec, Octopus ${ }^{\mathrm{TM}}$ ) with individual chambers dedicated to intrinsic and doped layer deposition. The inter-electrode gap for this system is $15 \mathrm{~mm}$ and the chambers are powered at 13.56 MHz. For the layer depositions, mixtures of the following gases were used: silane $\left(\mathrm{SiH}_{4}\right)$, hydrogen $\left(\mathrm{H}_{2}\right)$, trimethylborane $\left(\mathrm{B}\left(\mathrm{CH}_{3}\right)_{3}, \mathrm{TMB}\right)$ and phosphine $\left(\mathrm{PH}_{3}\right)$ for doping and carbon dioxide $\left(\mathrm{CO}_{2}\right)$ as the oxygen source. The layers were co-deposited on wafers and glass samples for layer characterization, as will be described later. After PECVD, the effective minority-carrier lifetimes $\left(\tau_{\text {eff }}\right)$ of the cell precursors were measured using a Sinton Consulting WCT-100 quasi-steady-state photoconductance system. ${ }^{23}$ This measurement was also used to extract the so-called implied $V_{\mathrm{oc}}{ }^{23}$ The next step was the deposition of ITO by sputtering on both the front and rear (see Ref. 24 for further details), and the deposition of a silver contact at the rear either by sputtering or evaporation. To finish the cells, the front metallization grid was screen-printed using a low-temperature silver paste, which was subsequently cured on a belt furnace at temperatures below $200{ }^{\circ} \mathrm{C}^{25}$ The entire cell fabrication process used in this work is fully compatible with industrial standards.

The cells were characterized using standard (AM 1.5 G) current-voltage $(J-V)$ measurements at ambient or higher temperatures (up to the setup limit of $55^{\circ} \mathrm{C}$ ), as well as suns$V_{\text {oc }}$ measurements. $^{26}$ Furthermore, systematic spectral response and reflectance measurements were conducted to determine external quantum efficiency $(E Q E)$, reflectance $(R)$, and internal quantum efficiency $(I Q E)$.

Spectroscopic ellipsometry (SE) was used to characterize the layers that were co-deposited on glass. Using a TaucLorentz multi-layer model to fit the data, the refractive index $n$, the extinction coefficient $k$, the optical bandgap $E_{04}$ (determined at an absorption coefficient $\alpha=10^{4} \mathrm{~cm}^{-1}$ ) and the layer thickness were extracted. Unless stated differently, the layer thicknesses refer to the thicknesses on a textured wafer, i.e., thicknesses measured on a flat substrate (glass) divided by a geometrical factor of $1.7 .^{1}$

Thermal desorption spectroscopy (TDS) was used to investigate the bonding configuration of hydrogen within $i$ a$\mathrm{SiO}_{\mathrm{x}}: \mathrm{H}$ passivation layers. For this measurement, the sample (typically a piece of c-Si with the layer on top) was heated in ultra-high vacuum and the gases desorbed from it were analyzed by a quadrupole mass spectrometer. More details can be found elsewhere. ${ }^{27}$

Furthermore, we used Fourier transform infrared spectroscopy (FTIR) in perpendicular transmittance mode to verify the presence of oxygen for an approximately 95 -nm-thick layer. This was done by analyzing the modes of $\mathrm{Si}-\mathrm{O}$ centered at around $1000 \mathrm{~cm}^{-1}$ and $1150 \mathrm{~cm}^{-1}$ (Ref. 28) as well as the mono-hydride and multi-hydride modes at $2010 \mathrm{~cm}^{-1}$ and $2100 \mathrm{~cm}^{-1}$, respectively (Ref. 29).

\section{RESULTS AND DISCUSSION}

\section{A. Passivation properties of $i$ a-SiO $: \mathrm{H}$}

To evaluate the passivation and optical properties of $i$ a$\mathrm{SiO}_{\mathrm{x}}: \mathrm{H}$ films, double-side polished, (100), 300- $\mu$ m-thick phosphorous-doped wafers with a resistivity of $4 \Omega \mathrm{cm}$ were passivated by $16-\mathrm{nm}$-thick layer stacks deposited on both sides. These stacks consisted of a very thin $i$ a-Si:H layer ( $\sim 2 \mathrm{~nm}$, from ellipsometry), on which an $\mathrm{a}-\mathrm{SiO}_{\mathrm{x}}: \mathrm{H}$ layer of varying composition was deposited. This was done since direct deposition of $i \mathrm{a}-\mathrm{SiO}_{\mathrm{x}}: \mathrm{H}$ layers on the wafer surfaces resulted in systematically poor passivation (results not shown). In the remainder of the text, the presence of such thin $i$ a-Si:H layers is implicitly assumed. The effective minority-carrier lifetime $\left(\tau_{\text {eff }}\right)$ of each passivated sample was measured both in the as-deposited state as well as after annealing at $200^{\circ} \mathrm{C}$ for $100 \mathrm{~min}$ in air (Fig. 2). The approximate effective surface recombination velocity $\left(S_{\text {eff }}\right)$ was calculated from the following equation for $\tau_{\text {eff }}$ (with wafer thickness $W$ ):

$$
\frac{1}{\tau_{e f f}}=2 \frac{S_{e f f}}{W} .
$$

Equation (1) assumes symmetric passivation at the front and rear surfaces and a bulk lifetime of $\tau_{\text {bulk }} \rightarrow \infty$. Excellent as-deposited lifetimes of $\tau_{\text {eff }}>5 \mathrm{~ms} \quad\left(S_{\text {eff }}<3 \mathrm{~cm} / \mathrm{s}\right)$ are obtained across the entire input gas flow ratio range. Samples passivated by silicon-rich films show a clear further improvement in passivation upon low-temperature annealing, a phenomenon well-known for pure a-Si:H films. ${ }^{30}$ The samples fabricated with $\mathrm{CO}_{2} / \mathrm{SiH}_{4}$ gas flow ratios higher than 0.8 show a slightly lower $\tau_{\text {eff }}$ and a smaller increase in 


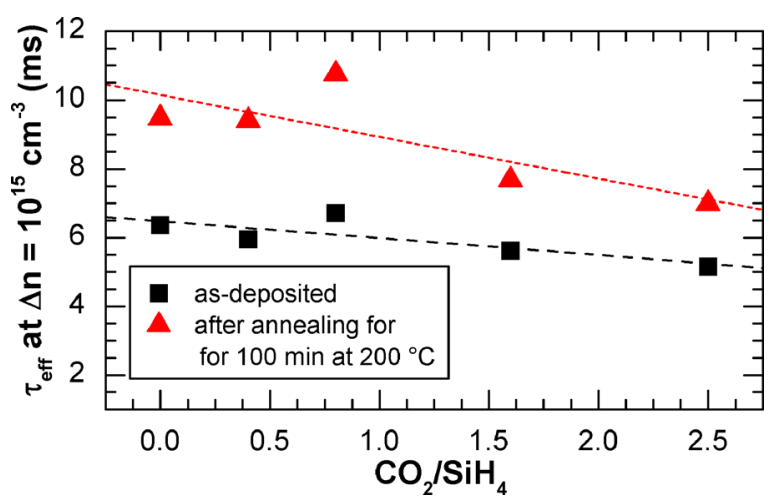

FIG. 2. Effective minority-carrier lifetimes (at an excess carrier density of $\Delta n=10^{15} \mathrm{~cm}^{-3}$ ) before and after annealing for $100 \mathrm{~min}$ at $200{ }^{\circ} \mathrm{C}$ in air for $n$-type float-zone wafers passivated with approximately 16 -nm-thick $i$ a-SiO $\mathrm{x}: \mathrm{H}$ stacks deposited with different $\mathrm{CO}_{2} / \mathrm{SiH}_{4}$ input flow ratios. The trend lines are guides for the eye.

passivation quality upon annealing compared to the samples fabricated at lower $\mathrm{CO}_{2} / \mathrm{SiH}_{4}$ gas flow ratios (Fig. 2).

One possible explanation for this slight drop in passivation quality may be the increasingly porous character of the layers. An indication of such porosity was observed by TDS measurements on layers deposited directly, without a thin $i$ a-Si:H layer, on double-side polished wafers (Fig. 3). For pure a-Si:H films, typically a high- and a low-temperature $\mathrm{H}_{2}$ desorption peak are present and are usually taken, respectively, as signatures for the release of $\mathrm{H}_{2}$ from mono-hydrides and for the presence of hydrogenated voids in the material. ${ }^{31,32}$ Here, for an increasing $\mathrm{CO}_{2} / \mathrm{SiH}_{4}$ ratio, a clear decrease of the high-temperature peak signal and a simultaneous increase of the low-temperature peak signal is observed, pointing to increased porosity. Similar results have been reported by Einsele et al. ${ }^{20}$ With TDS and FTIR measurements, they showed that by adding oxygen to the layer its microstructure is changed significantly. For higher oxygen contents, they observed an increase in the stretching mode at $2100 \mathrm{~cm}^{-1}$, which is attributed to hydrogen-terminated voids in the material. ${ }^{33,34}$ According to Refs. 35 and 36, termination with higher hydrides, which is related to a higher void fraction and defect density, is less favorable for passivation, which explains our results in Fig. 2. Besides extracting

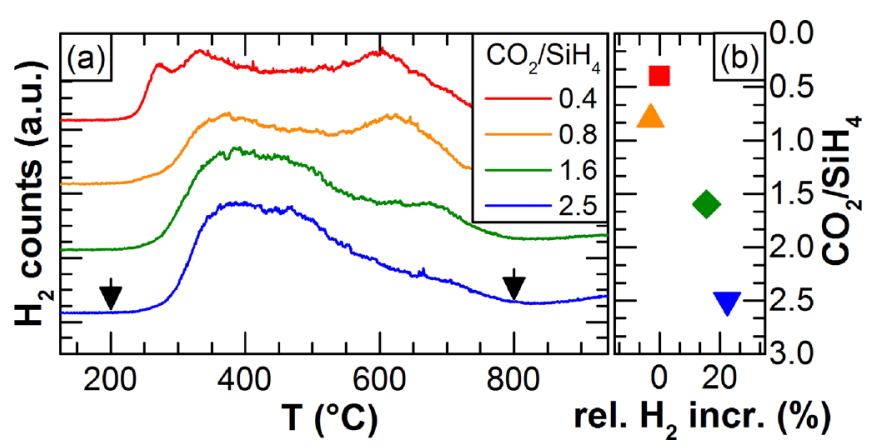

FIG. 3. (a) TDS data of $\mathrm{H}_{2}(m / z=2)$ taken for $i$ a-SiO ${ }_{\mathrm{x}}: \mathrm{H}$ layers deposited directly on polished wafers, i.e., without an $i$ a-Si:H layer beneath. The measurements were normalized to the volume of the corresponding layer and the curves are offset for clarity. The arrows indicate the range used for integration $\left(200-800^{\circ} \mathrm{C}\right)$. (b) Relative $\mathrm{H}_{2}$ increase for the layers shown in (a), normalized to the layer deposited with $\mathrm{CO}_{2} / \mathrm{SiH}_{4}=0.4$. information about the porosity, the TDS data were also used to study the hydrogen content in the layers. To do this, the $\mathrm{H}_{2}$ effusion signals (normalized to the volume of the respective layers) shown in Fig. 3(a) were integrated from 200 to $800^{\circ} \mathrm{C}$. An increase of $\mathrm{CO}_{2} / \mathrm{SiH}_{4}$ input flow ratio from 0.4 to 2.5 results in a relative increase in hydrogen content in the layer of $22.5 \%$ (Fig. 3(b)).

\section{B. Optical properties of $i \mathrm{a}-\mathrm{SiO}_{\mathrm{x}}: \mathrm{H}$}

Figure 4(a) shows the evolution of $n$ and $k$ obtained from SE measurements for an increasing $\mathrm{CO}_{2} / \mathrm{SiH}_{4}$ input flow ratio. Both parameters decrease, while $E_{04}$ (Fig. 4(b)) increases. ${ }^{19}$ These effects can be attributed to the increased incorporation of either oxygen ${ }^{37}$ or hydrogen into the silicon matrix (and the associated increase in the void fraction in the layer). ${ }^{38-42}$ For our films, both effects likely contribute. With the findings reported in Ref. 41 and the assumption that the trends reported there are also valid for the $E_{04}$ value, we calculated the change in bandgap one would expect from the increase in hydrogen extracted from the TDS data. We used the bandgap $E_{04}=2.04 \mathrm{eV}$ of the a- $\mathrm{SiO}_{\mathrm{x}}: \mathrm{H}$ layer deposited at $\mathrm{CO}_{2} / \mathrm{SiH}_{4}=0.4$ as a starting point; this corresponds to approximately $26.8 \%$ of hydrogen (atomic). Compared to the standard a-Si:H layer $\left(E_{04}=1.98 \mathrm{eV}\right)$, this represents already an increase of approximately $6.4 \%$ of hydrogen (atomic) ${ }^{41}$ The $22.5 \%$ relative increase from $\mathrm{CO}_{2} / \mathrm{SiH}_{4}=0.4$ to 2.5 (obtained from TDS, see Sec. III A) amounts to approximately an additional $5.9 \%$ of hydrogen (atomic). However, based on Ref. 41, this is not quite sufficient to explain the total increase of $E_{04}$ to $2.12 \mathrm{eV}$ (measured for the a-SiO $\mathrm{x}: \mathrm{H}$ layer deposited at a flow ratio of $\left.\mathrm{CO}_{2} / \mathrm{SiH}_{4}=2.5\right)$, as it leads to an increase of only $60 \mathrm{meV}$ to $2.10 \mathrm{eV}$. Thus, we attribute the remaining difference between the calculated and measured $E_{04}$ values, of $20 \mathrm{meV}$, to the effect of the oxygen content in the layer, which we believe to be considerably lower than that of hydrogen. The incorporation of oxygen into an

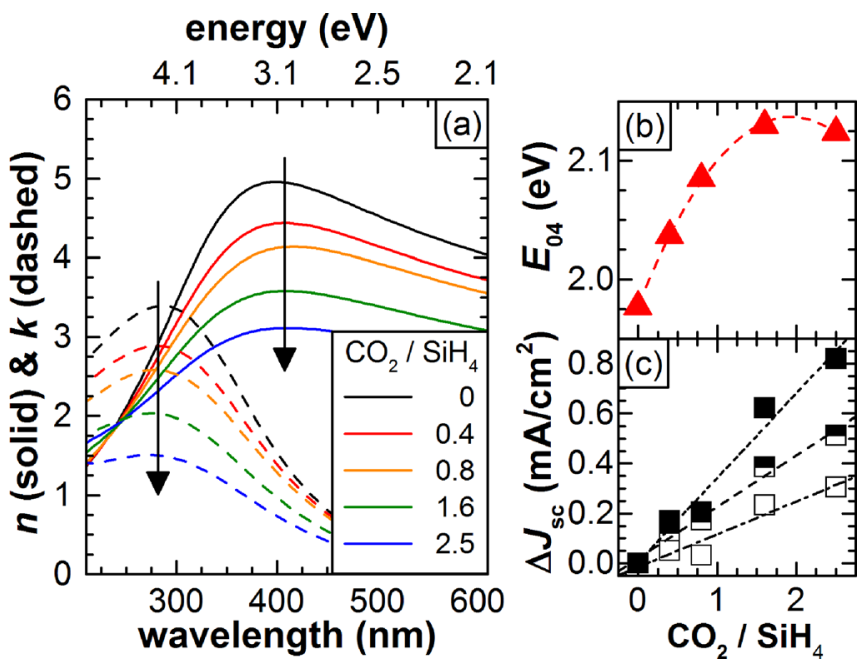

FIG. 4. (a) Refractive index $n$ (solid) and extinction coefficient $k$ (dashed) of $i$ a-SiO $\mathrm{S}_{\mathrm{x}} \mathrm{H}$ layers as a function of wavelength/energy for layers deposited with increasing $\mathrm{CO}_{2} / \mathrm{SiH}_{4}$ input flow ratios (direction indicated by arrows). (b) Optical bandgap $E_{04}$ extracted from $\mathrm{SE}$ and (c) calculated gain in current density between 300 and $600 \mathrm{~nm}$ (half-filled symbols), 600-1200 nm (open symbols) and the total gain (filled symbols), as a function of $\mathrm{CO}_{2} / \mathrm{SiH}_{4}$ ratio. 
approximately 94-nm-thick layer deposited on a double-side polished (100) wafer at a $\mathrm{CO}_{2} / \mathrm{SiH}_{4}$ gas ratio of 2.5 was confirmed by FTIR measurements. In contrast to our standard $i$-layers, ${ }^{43}$ we observed a significantly higher absorbance for the mode centered around $2100 \mathrm{~cm}^{-1}$ compared to the mode at $2000 \mathrm{~cm}^{-1}$ (Fig. 5). This points to more hydrogen-terminated voids, which confirms our results obtained from TDS. Note that compared to the standard $i$ $\mathrm{a}-\mathrm{Si}: \mathrm{H}$ layer, the spectrum for the $i \mathrm{a}-\mathrm{SiO}_{\mathrm{x}}: \mathrm{H}$ layer exhibits additional peaks at higher wavenumbers $\left(\mathrm{SiH}(\mathrm{O} 3), \mathrm{SiH}_{2}(\mathrm{O} 2)\right.$, and $\mathrm{SiH}_{2}(\mathrm{SiO})$, Fig. 5). These can be attributed to oxygen present in the layer. ${ }^{44}$ Both the increasing amount of hydrogen and-for our case, to a minor extent-oxygen may lead to an increasing valence band (VB) offset. ${ }^{41,45}$ This can explain the significant effect on carrier collection we observe in our devices, which will be discussed in Sec. III C.

To assess the potential current gain $\left(\Delta J_{\mathrm{sc}}\right)$ that can be expected with such wider bandgap films, we used the $n$ and $k$ values as input for $\mathrm{OPAL}^{46}$ simulations. The parasitic absorption in a device-relevant stack of ITO $(70 \mathrm{~nm}), p^{+}$ $\mathrm{a}-\mathrm{Si}: \mathrm{H}(6 \mathrm{~nm})$ and $i \mathrm{a}-\mathrm{Si}: \mathrm{H}$ or $i \mathrm{a}-\mathrm{SiO}_{\mathrm{x}}: \mathrm{H}(6 \mathrm{~nm})$ on a textured wafer was calculated for different oxygen contents. We then determined an equivalent short-circuit current density $\left(J_{\text {eq }}\right)$ lost through parasitic absorption in the three front layers by integrating the product of absorption and photon flux (standard $\mathrm{AM} 1.5 \mathrm{G}$ spectrum) from 300 to $600 \mathrm{~nm}$ and 600 to $1200 \mathrm{~nm}$. We thereby obtained a potential total gain of up to $0.81 \mathrm{~mA} / \mathrm{cm}^{2} \quad\left(300-600 \mathrm{~nm}: \quad 0.51 \mathrm{~mA} / \mathrm{cm}^{2}, \quad 600-1200 \mathrm{~nm}\right.$ : $0.31 \mathrm{~mA} / \mathrm{cm}^{2}$ ) for a layer deposited at a $\mathrm{CO}_{2} / \mathrm{SiH}_{4}$ ratio of 2.5 (Fig. 4(c)). We attribute this gain to an increase of the optical bandgap (Fig. 4(b)) and a change in total reflectance (R, see Figs. 6(b) and 6(d)).

The latter was also extracted from the same set of simulation data and shows a decrease especially between 300-400 and 600-1200 nm (not shown here). This decrease is more pronounced for higher $\mathrm{CO}_{2} / \mathrm{SiH}_{4}$ ratios and thicker layers, and is caused by the low- $n$ a-SiO $:$ :H layer, which acts like an additional anti-reflection coating between the TCO and the silicon.

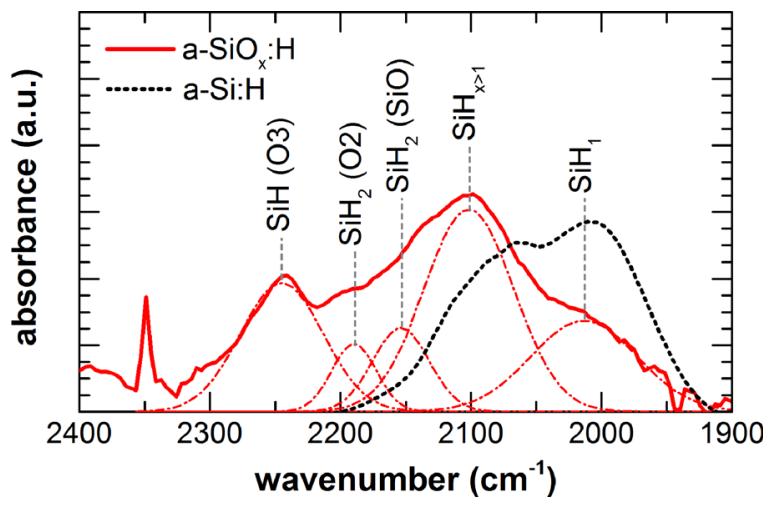

FIG. 5. Comparison of FTIR spectra (raw data). The dotted black line shows the spectrum taken for the standard $i$ a-Si:H layer $(7 \mathrm{~nm}$, measured in attenuated total reflection configuration, taken from Ref. 43) whereas the solid red line refers to a 95-nm-thick layer of $i$ a-SiO $\mathrm{S}_{\mathrm{x}}: \mathrm{H}$ (measured in transmission mode, thus the need for a thick layer). The dashed-dotted lines represent the peaks used for fitting the $\mathrm{a}-\mathrm{SiO}_{\mathrm{x}}: \mathrm{H}$ data. See Ref. 44 for more details on the oxide-related peaks.
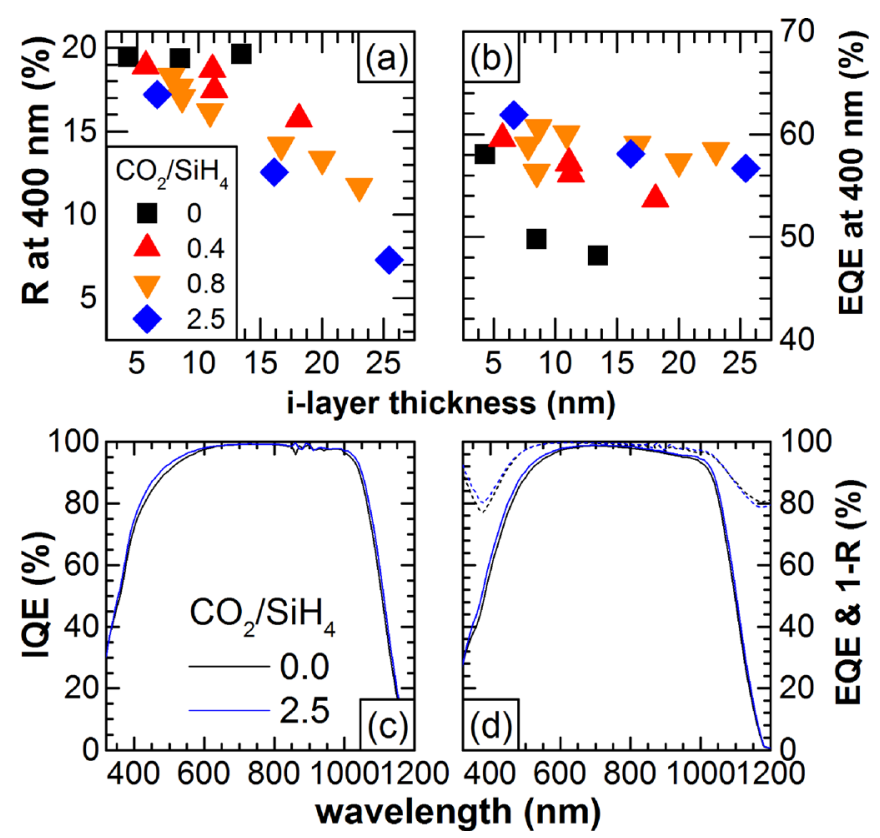

FIG. 6. (a) Reflectance and (b) $E Q E$ at $400 \mathrm{~nm}$ for different $i$-layer thicknesses and different $\mathrm{CO}_{2} / \mathrm{SiH}_{4}$ ratios. (c) and (d) $I Q E, E Q E$ and $1-R$ as a function of wavelength.

In a next step, we fabricated solar cells and implemented either standard $i$ a-Si:H (both sides, standard cell) or $i$ a$\mathrm{SiO}_{\mathrm{x}}: \mathrm{H}$ (front only) passivation layers. We varied both the $\mathrm{CO}_{2} / \mathrm{SiH}_{4}$ gas flow ratio and the layer thickness, and we obtained an increase of approximately $0.43 \mathrm{~mA} / \mathrm{cm}^{2}$ for $\sim 6$-nm-thick a- $\mathrm{SiO}_{\mathrm{x}}: \mathrm{H}$ passivation layer deposited at $\mathrm{CO}_{2} / \mathrm{SiH}_{4}=2.5$. Comparing the $E Q E$ and $I Q E$ data of both cells, the gain in the range of $300-600 \mathrm{~nm}$ is of $0.27 \mathrm{~mA} / \mathrm{cm}^{2}$ while for the range $600-1200 \mathrm{~nm}$ we see a gain of $0.29 \mathrm{~mA} / \mathrm{cm}^{2}$, which amounts to a total gain of $0.56 \mathrm{~mA} / \mathrm{cm}^{2}{ }^{2} .7$ The fact that the increase in current is a result of the widening bandgap and an anti-reflective effect is confirmed by these results from real devices (Figs. 6(a)-6(d)). While $R$ at $400 \mathrm{~nm}$ is constant for the standard a-Si:H layers — which have nearly the same $n$ as c-Si-as their thickness is increased, we see a decrease in $R$ for all of the a- $\mathrm{SiO}_{\mathrm{x}}: \mathrm{H}$ layers. This explains why the EQE (at $400 \mathrm{~nm}$ ) of the cells with oxide layers shows only a weak thickness dependence (Fig. 6(b); parasitic absorbance increases but $R$ decreases), whereas we see a strong dependence for the standard a-Si:H layers.

\section{Application of $i \mathrm{a}-\mathrm{SiO}_{\mathrm{x}}: \mathrm{H}$ in solar cells}

Figure 7 shows the illuminated $J-V$ parameters of solar cells featuring $i$ a-SiO $: \mathrm{H}$ buffer layers of various thickness and composition. Some of the $J-V$ curves are strongly s-shaped and the voltage measured at zero current (in some cases above $830 \mathrm{mV}$ ) exceeds the theoretical limit $^{48}$ for c-Si. ${ }^{1}$ Hence, rather than showing the 1 -sun $V_{\text {oc }}$ values, we show the implied $V_{\mathrm{oc}}$ values obtained from lifetime measurements as an indication of the level of passivation. Also, in devices, the $\mathrm{CO}_{2} / \mathrm{SiH}_{4}$ ratio has only a minor influence on the passivation quality (Fig. 7(a)), which is high for all of the cells, as evidenced by the implied $V_{\text {oc }}$ values in excess of $720 \mathrm{mV}$. 


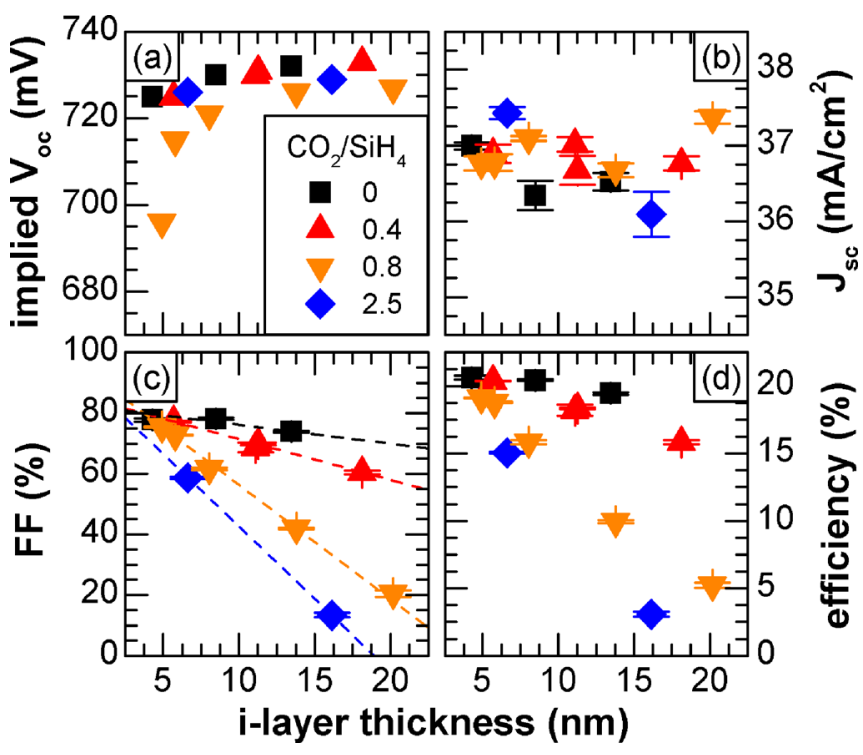

FIG. 7. (a) Implied open-circuit voltage, (b) short-circuit current density, (c) fill factor (the dashed lines are linear fits to the data) and (d) cell efficiency as a function of the front $i$-layer thickness (on textured wafers). The data points represent the average of three cells on the same wafer. The error bars indicate the standard error of the mean. Note that the series at a ratio of 0.8 featured a different batch of wafers, i.e., different cleaning and texturization, than the others; hence the slight differences in implied open-circuit voltage.

For the devices exhibiting similar $i$-layer thicknesses below $7.5 \mathrm{~nm}$, note that, except for the device with an $i$-layer deposited at $\mathrm{CO}_{2} / \mathrm{SiH}_{4}=2.5, J_{s c}$ is not higher for the cells with $i$ a-SiO $: \mathrm{H}$ layers (Fig. 7(b)), as would be expected from the EQE values at $400 \mathrm{~nm}$ (Fig. 6(b)). This is due to similar or lower EQE values at longer wavelengths (data not shown) compared to the reference sample (thinnest $i$-layer), possibly either due to small reflection or mere sample-tosample variations. Hence, for those cells more light is lost in the red than gained in the blue part of the light spectrum, and the $J_{\mathrm{sc}}$ is slightly lower than the reference.

For devices with standard $i$ a-Si:H layers, the $F F$ shows a slight dependence on $i$-layer thickness. However, increasing the $\mathrm{CO}_{2} / \mathrm{SiH}_{4}$ ratio increases the $F F$ 's sensitivity to thickness significantly, as can be seen in the different trends shown in Fig. 7(c). The decrease in $F F$ with increasing $\mathrm{CO}_{2} / \mathrm{SiH}_{4}$ ratio is most likely due to the change in the band offset at the interface ${ }^{41}$ and is in agreement with findings by Shu et al. ${ }^{49}$ Using simulations, they linked a decrease in $F F$ to an increase in buffer layer bandgap. In our case, collecting the holes at the front, an increased VB offset at the interface between the wafer and buffer layer may be especially detrimental, as the holes face a higher effective barrier than electrons would (namely, the conduction band (CB) offset), making their collection less efficient.

To assess the influence of this barrier on hole transport, we conducted $J-V$ measurements on a standard cell $(i$ a-Si:H buffer, $\sim 6 \mathrm{~nm}$ thick, Fig. $8(\mathrm{a}))$ and a cell with an a-SiO $\mathrm{x}: \mathrm{H}$ passivation layer $\left(\mathrm{CO}_{2} / \mathrm{SiH}_{4}=0.8, \sim 6 \mathrm{~nm}\right.$ thick, Fig. 8(b)) at different temperatures. When increasing the temperature from $25^{\circ} \mathrm{C}$ to $55^{\circ} \mathrm{C}$, the $V_{\text {oc }}$ decreases by roughly $50 \mathrm{mV}$ for both cells due to an increase in dark saturation current density through the increase of the intrinsic carrier density $\left(n_{\mathrm{i}}\right)$.
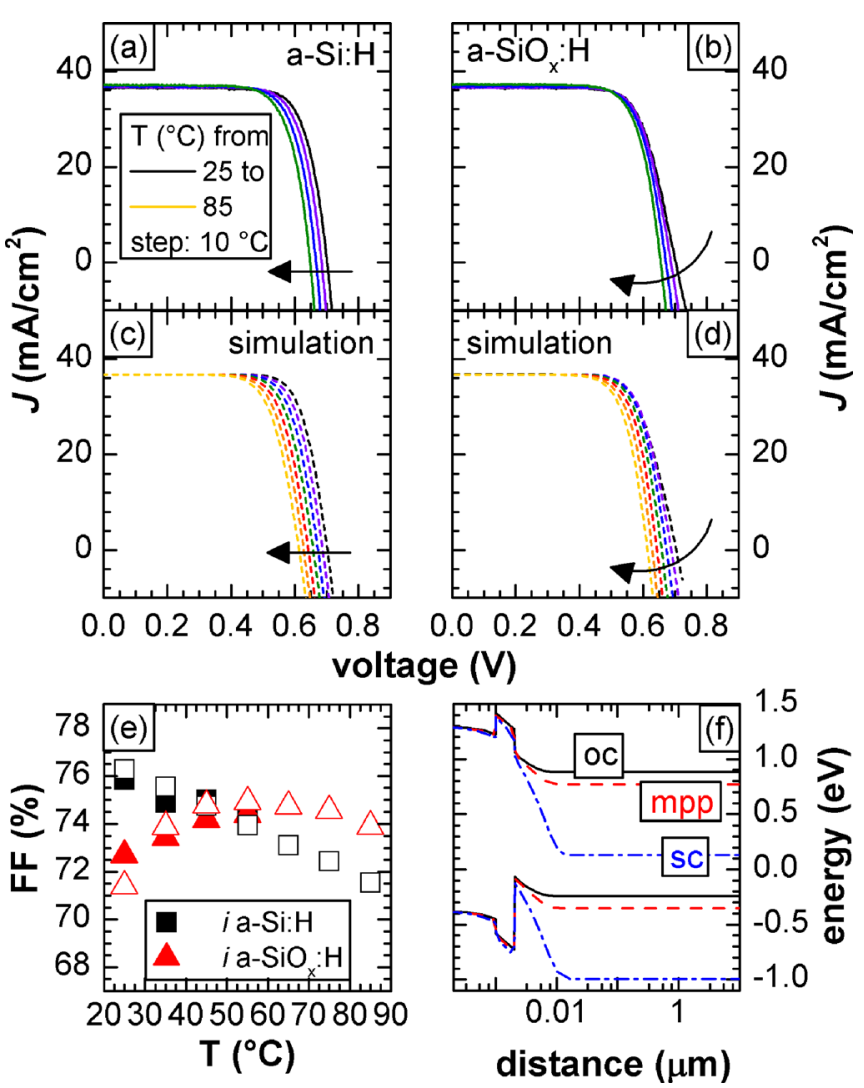

FIG. 8. (a), (b) $J-V$ measurements (temperature: $25-55^{\circ} \mathrm{C}$ in steps of $10^{\circ} \mathrm{C}$ ) and (c), (d) simulations $\left(25-85^{\circ} \mathrm{C}\right.$, in steps of $\left.10^{\circ} \mathrm{C}\right)$ for devices with an $i$ a$\mathrm{Si}: \mathrm{H}$ or $i \mathrm{a}-\mathrm{SiO}_{\mathrm{x}}: \mathrm{H}$ front passivation layer. The arrows indicate the increasing temperature and illustrate the different behaviors. (e) $F F$ evolution with temperature (filled symbols: $J-V$ measurements, open symbols: simulation) for both cells. (f) $\mathrm{PC}^{5} \mathrm{D}^{52}$ simulation of the energy bands close to the $\mathrm{a}-\mathrm{SiO}_{\mathrm{x}}: \mathrm{H} / \mathrm{c}-\mathrm{Si}$ interface in short-circuit (sc), at maximum power point (mpp) and in open-circuit (oc) conditions.

However, compared to the reference, the $\mathrm{a}-\mathrm{SiO}_{\mathrm{x}}: \mathrm{H}$ cell shows a slightly lower absolute value of the relative change in $V_{\mathrm{oc}},-0.22 \% /{ }^{\circ} \mathrm{C}$ instead of $-0.25 \% /{ }^{\circ} \mathrm{C}$ (data not shown). Furthermore, besides this effect, the standard cell shows a decrease in $F F$ of approximately $2 \%$ absolute, whereas the cell with an oxide layer recovers almost $2 \%$ for the same temperature range (Fig. 8(e)). This improvement confirms earlier findings for wide-bandgap a-SiC:H buffer layers. ${ }^{50}$ Due to a more favorable (efficiency) temperature coefficient $\beta \sim-0.1 \% /{ }^{\circ} \mathrm{C}$ (compared to $-0.3 \% /{ }^{\circ} \mathrm{C}$ for the reference) in the investigated temperature range, the cell with an implemented oxide buffer layer shows an efficiency which, at high temperatures-those closer to real working conditions in the field-is superior to the standard cell design (Fig. 9). At $55^{\circ} \mathrm{C}$, the cell with an oxide buffer layer exhibits an efficiency of $18.0 \%\left(18.6 \%\right.$ at $\left.25^{\circ} \mathrm{C}\right)$, compared to $17.7 \%$ $\left(19.6 \%\right.$ at $\left.25^{\circ} \mathrm{C}\right)$ obtained from the reference cell. A similar effect has been reported in a simulation study by Rahmouni et al. ${ }^{51}$ where thicker buffer layers lead to favorable temperature coefficients due to improving $F F$. However, in contrast to our findings for a-SiO ${ }_{\mathrm{x}}: \mathrm{H}$ layers, devices with thicker $i$ a-Si:H passivation layers do not show a better performance at elevated temperatures. Their efficiencies stay below the efficiency of the reference device with a 3-nm-thick $i$ a-Si:H layer. 


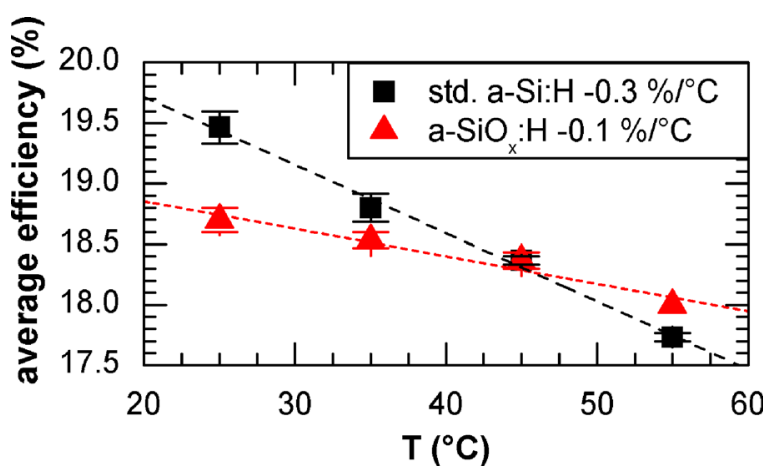

FIG. 9. Efficiency as a function of temperature of a standard cell with $i$ a$\mathrm{Si}: \mathrm{H}$ buffer layers (see Fig. 8(a)) and a cell with an $i \mathrm{a}-\mathrm{SiO}_{\mathrm{x}}: \mathrm{H}$ buffer layer at the front (see Fig. 8(b)). The trend lines represent linear fits to the data. The slopes of $-0.056 \% /{ }^{\circ} \mathrm{C}$ and $-0.023 \% /{ }^{\circ} \mathrm{C}$ represent the absolute changes in efficiency with temperature, which lead to temperature coefficients of $-0.3 \% / ;{ }^{\circ} \mathrm{C}$ and $-0.1 \% /{ }^{\circ} \mathrm{C}$, respectively. ${ }^{5}$

To better understand the observed trends in $F F$ for our devices, one-dimensional device simulations were carried out using the software packages SunShine ${ }^{53}$ and ASPIN2 $2^{54}$ for the optical and electrical models, respectively. To obtain the generation-rate profile throughout the cell, a 70-nm-thick front ITO layer (anti-reflective coating) and a 150-nm-thick rear ITO layer with $300 \mathrm{~nm}$ of $\mathrm{Ag}$ (rear reflector) were added. The simulations were done on flat layers, yet in order to simulate a textured wafer and match the measured $J_{s c}$, the reflection at the front was reduced by $17.5 \%$. Furthermore, the $n$ and $k$ data of the relevant layers obtained from SE were used. $^{55}$

For electrical simulations, the surface defect density at both the front and rear a-Si:H/c-Si interfaces was set to $5 \times 10^{10} \mathrm{~cm}^{-2}$ to match the measured $V_{\mathrm{oc}}$. The parameters of the different materials were chosen as described in Table I. We assumed the same electron affinity for all of the amorphous layers, i.e., only the VB offset ${ }^{41}$ varied upon changing the bandgap of the $\mathrm{a}-\mathrm{SiO}_{\mathrm{x}}: \mathrm{H}$ layer from $1.7 \mathrm{eV}$ to $1.9 \mathrm{eV}$, whereas the $\mathrm{CB}$ offset remained constant. This reflects the assumption we made that mainly the VB position changes upon hydrogen incorporation and widening of the bandgap. ${ }^{41}$ For simplicity, only thermionic emission across the barrier was included in the simulations; neither the temperature dependence of the bandgaps, Auger recombination, nor tunneling at the heterointerface was taken into account.

Figures $8(\mathrm{c})$ and $8(\mathrm{~d})$ show the simulated $J-V$ curves $\left(25-85^{\circ} \mathrm{C}\right.$, step size of $10^{\circ} \mathrm{C}$ ) corresponding to the measured $J-V$ curves in Figures $8(\mathrm{a})$ and $8(\mathrm{~b})\left(25-55^{\circ} \mathrm{C}\right.$, step size of $10^{\circ} \mathrm{C}$ ). Remarkably, similar trends were obtained with the simulations, especially for the $F F$ (Fig. 8(e)). We therefore conclude that the drop in $F F$ we observed in cells with thin $\mathrm{a}-\mathrm{SiO}_{\mathrm{x}}: \mathrm{H}$ passivation layers must indeed be a result of impeded hole collection due to a higher VB offset ${ }^{51,56}$ which leads to an accumulation of holes. ${ }^{57}$ The effect depends on the working point of the device and becomes more significant when moving from short-circuit to open-circuit conditions. In short-circuit conditions, there is strong band bending, as indicated in Fig. 8(f). Therefore, holes are easily collected across the junction thanks to a high electric field, and hole accumulation at the interface is kept low. However, moving towards open-circuit conditions, the bands flatten (Fig. 8(f)), and the accumulation of holes at the interface increases. It has been reported that this accumulation of holes at the interface can lead to a strong increase of recombination and thus to a reduction of the photocurrent ${ }^{58}$ and thus, in our case, of the $F F$. This effect is one possible explanation for the behavior we obtain for our devices.

The increase in $F F$ with temperature observed for cells with $\mathrm{a}-\mathrm{SiO}_{\mathrm{x}}: \mathrm{H}$ buffer layers points then to enhanced carrier transport, probably due to thermionic emission of the holes over the barrier at maximum power point. We remark that optimized standard devices are considered to operate in a carrier-diffusion-limited regime, very similar to homojunction devices (Ref. 59). In this case, the decrease in $F F$ with increasing temperature is likely a consequence of the standard temperature-induced drop in voltage at the maximum-power point. This is most likely linked to the detrimental temperature dependency of the dark saturation current density. The increase in line resistance with temperature plays only a negligible role due to the small resistivity temperature coefficient of silver.

In order to investigate further the influence of the VB offset, we performed another set of simulations using the same model as described before $\left(\mathrm{a}-\mathrm{SiO}_{\mathrm{x}}: \mathrm{H}\right.$ cell, Table I). However, this time we varied the electron affinity $\left(E_{a}\right.$, Fig. $10(\mathrm{~d})$ ) of the $i \mathrm{a}-\mathrm{SiO}_{\mathrm{x}}: \mathrm{H}$ buffer layer while keeping the other parameters fixed. Changing its value from $3.72 \mathrm{eV}$ to $3.92 \mathrm{eV}$, both the CB and VB edge move down in energy and the VB offset increases by $0.2 \mathrm{eV}$ from (1) that of the reference cell to (2) that assumed for the oxide cell (Fig. 10(a)). This has the same effect on the $F F$ as we observed in our experiments when increasing the $\mathrm{CO}_{2} / \mathrm{SiH}_{4}$ ratio and confirms that it is the $\mathrm{VB}$ offset that hinders the carriers from being collected efficiently and that lowers $F F$ at room temperature. To further underline this fact, two additional series of simulations were performed. This time the VB offset was fixed to the values of positions (1) and (2) in Fig. 10(a) and the CB offset was varied by changing both the electron affinity and the bandgap at the same time (Figs. 10(b) and 10(c)).

TABLE I. Parameters used for simulations of a standard cell with an a-Si:H passivation layer, and of a cell with an a-SiO ${ }_{\mathrm{x}} \mathrm{H}$ front passivation layer.

\begin{tabular}{lccc}
\hline \hline Layer & $p$ a-Si:H & $n$ a-Si:H & $i$ a-Si:H/a-SiO $: H$ \\
\hline Thickness & $10 \mathrm{~nm}$ & $10 \mathrm{~nm}$ & $8.5 \mathrm{~nm}$ \\
Bandgap $(\mathrm{eV})$ & 1.7 & 1.7 & $230 \mu \mathrm{m}$ \\
Electron affinity $(\mathrm{eV})$ & 3.924 & 3.924 & $1.7 / 1.9$ \\
Doping concentration $\left(\mathrm{cm}^{-3}\right)$ & $1 \times 10^{19}$ & $1 \times 10^{19}$ & 3.924 \\
Electron/hole mobility $\left(\mathrm{cm}^{2} / \mathrm{Vs}\right)$ & $10 / 2$ & $10 / 2$ & 0 \\
\hline \hline
\end{tabular}



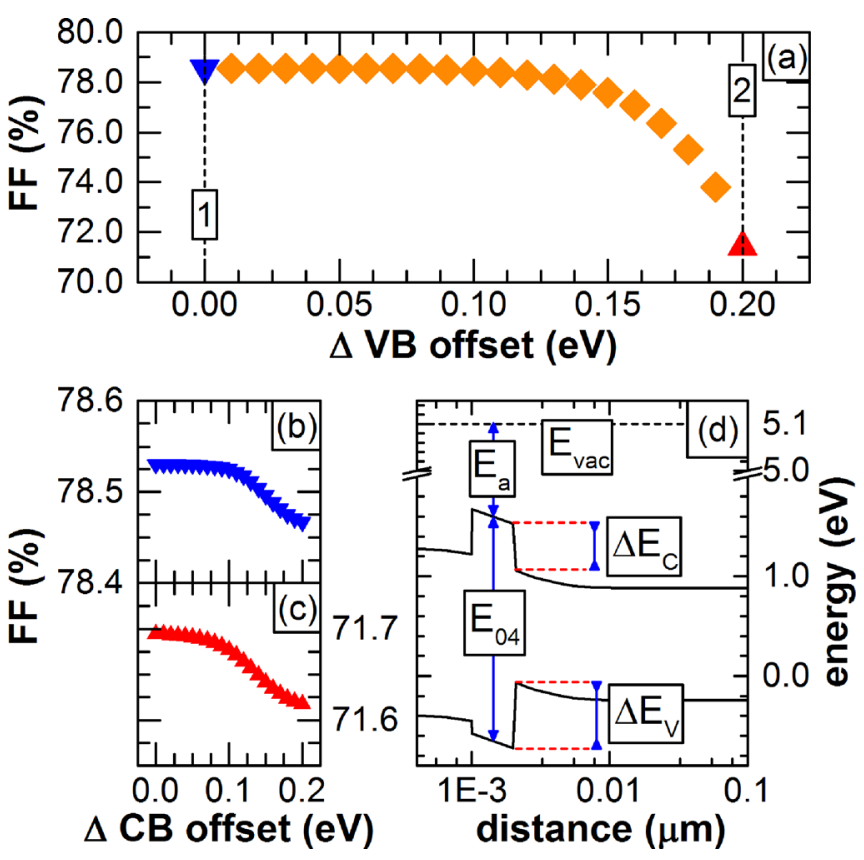

FIG. 10. (a) $F F$ as a function of the change in VB offset (variation of $\Delta \mathrm{E}_{\mathrm{V}}$ ). At position (1), the VB offset corresponds to the offset of the reference cell, whereas at position (2), it is approximately equal to the offset of the cell with an oxide buffer layer. (b) and (c) show the $F F$ as a function of the change in $C B$ offset (variation of $\Delta \mathrm{E}_{\mathrm{C}}$ ), keeping the $\mathrm{VB}$ offset constant at positions (1) and (2), respectively. (d) Schematic band diagram illustrating the energies varied in the simulations (electron affinity $E_{a}$ and vacuum level $\left.\mathrm{E}_{\mathrm{vac}}\right)$.

For both cases, the $F F$ shows only a weak dependence on the $\mathrm{CB}$ offset value. Therefore-even though an increase in $\mathrm{CB}$ offset or additional effects lowering the $F F$ cannot be excluded completely-we believe that it is the VB offset which mainly limits carrier (hole) transport.

\section{BEST CELL RESULTS}

Combining our findings, and following further optimization, our best cell with an $\mathrm{a}-\mathrm{SiO}_{\mathrm{x}}: \mathrm{H}$ passivation layer at the front $\left(\mathrm{CO}_{2} / \mathrm{SiH}_{4}=0.4\right)$ showed a $V_{\mathrm{oc}}$ of $716 \mathrm{mV}$, a $J_{\mathrm{sc}}$ of $37.1 \mathrm{~mA} / \mathrm{cm}^{2}$, a $F F$ of $76.8 \%$ and an efficiency of $20.4 \%$ (Fig. 11, dashed line). These values are quite close to those

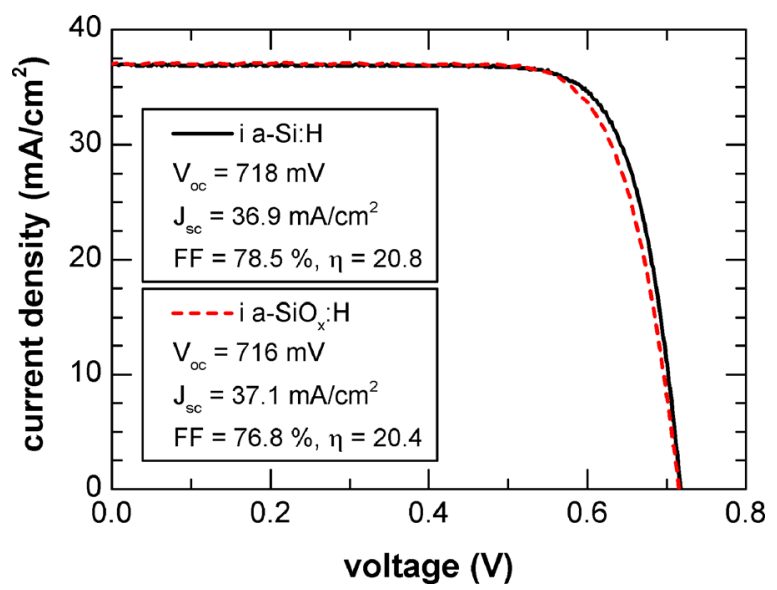

FIG. 11. Illuminated $J-V$ measurements of our best $2 \times 2 \mathrm{~cm}^{2}$ cells in these experiments, measured in house under standard test conditions. of the standard, reference cell in this experiment with a similar $i$-layer thickness, which reached a $V_{\mathrm{oc}}$ of $718 \mathrm{mV}$, a $J_{\mathrm{sc}}$ of $36.9 \mathrm{~mA} / \mathrm{cm}^{2}$, a $F F$ of $78.5 \%$ and an efficiency of $20.8 \%$ (Fig. 11, solid line). Although the $J_{\mathrm{sc}}$ increased by approximately $0.2 \mathrm{~mA} / \mathrm{cm}^{2}$ by using an $\mathrm{a}-\mathrm{SiO}_{\mathrm{x}}: \mathrm{H}$ passivation layer, the cell efficiency at room temperature decreased due to an absolute reduction in $F F$ of $1.7 \%$. Based on our device simulations, this limitation is likely to be fundamental, where an increase in $J_{\mathrm{sc}}$ by opening the bandgap of the buffer layer, and thereby increasing the VB offset, will be compensated by a drop in $F F$ resulting from impeded collection of holes.

\section{CONCLUSIONS}

We compared devices with $\mathrm{a}-\mathrm{SiO}_{\mathrm{x}}: \mathrm{H}$ passivation layers at the front to devices with standard a-Si:H passivation layers. No significant difference in passivation was observed and comparable implied $V_{\text {oc }}$ values of around $725 \mathrm{mV}$ were obtained. An increase in bandgap and a simultaneous decrease in short-wavelength reflection were observed with oxide layers. Both lead to an increase in $J_{\mathrm{sc}}$ of up to $0.43 \mathrm{~mA} / \mathrm{cm}^{2}$ for $\mathrm{CO}_{2} / \mathrm{SiH}_{4}=2.5$. Despite this gain-at room temperature - the expected improvement in efficiency is more than compensated for by losses in $F F$. Using simulations, we linked the $F F$ losses to an increased VB offset at the interface between the amorphous and crystalline phases, which results in a blockade for holes. This raises concerns whether wider bandgap window layers offer potential for improved device performance. Nevertheless, under the condition that it shows a good passivation quality and that the band lineup does not impede the carrier collection, a wide-bandgap buffer layer can be used. If the device will operate at elevated temperatures, the present design may be employed, as we found that a wide bandgap a-SiO $: \mathrm{H}$ buffer layer leads to a smaller absolute value of the temperature coefficient and to superior performance at elevated temperature compared to the standard cell. We note that, in many cases, the working conditions for a module in the field are actually in many cases far above room temperature, so the potential of these cells is obvious, especially for warmer climates.

Conversely, it may be preferable to collect electrons at the $\mathrm{a}-\mathrm{SiO}_{\mathrm{x}}: \mathrm{H}$ buffer layer side, as the larger $\mathrm{VB}$ offset should not impede electrons. In that case, the cell architecture should be redesigned towards a rear-emitter cell (when using $n$-type wafers). Otherwise, the polarity of the complete device needs to be changed by using $p$-type wafers and $n$-type electron collecting layers at the front.

\section{ACKNOWLEDGMENTS}

The authors would like to thank Roth \& Rau Research for wafer preparation, Jakub Holovsky for FTIR measurements, Nicolas Badel for front metallization, and Bénédicte Demaurex, Jonas Geissbühler and Loris Barraud for many fruitful discussions.

This work was supported by Axpo Naturstrom Fonds, the European Commission (FP7 project $20 \mathrm{pl} \mu \mathrm{s}$, Grant No. 256695), the EuroTech Universities Alliance and the Swiss Commission for Technology and Innovation. 
${ }^{1}$ S. De Wolf, A. Descoeudres, Z. C. Holman, and C. Ballif, Green 2, 7 (2012).

${ }^{2}$ D. L. Bätzner, Y. Andrault, L. Andreetta, A. Büchel, W. Frammelsberger, C. Guérin, N. Holm, D. Lachenal, J. Meixenberger, P. Papet, B. Rau, B. Strahm, G. Wahli, and F. Wünsch, in 26th European Photovoltaic Solar Energy Conference and Exhibition (Hamburg, Germany, 2011), p. 1073.

${ }^{3}$ A. Descoeudres, L. Barraud, S. De Wolf, B. Strahm, D. Lachenal, C. Guérin, Z. C. Holman, F. Zicarelli, B. Demaurex, J. P. Seif, J. Holovsky, and C. Ballif, Appl. Phys. Lett. 99, 123506 (2011).

${ }^{4}$ J. L. Hernandez, K. Yoshikawa, A. Feltrin, N. Menou, N. Valckx, E. Van Assche, J. Poortmans, D. Adachi, M. Yoshimi, T. Uto, H. Uzo, T. Kuchiyama, C. Allebe, N. Nakanishi, T. Terashita, T. Fujimoto, G. Koizumi, and K. Yamamoto, in 21st International Photovoltaic Science and Engineering Conference (Fukuoka, Japan, 2011).

${ }^{5}$ T. Kinoshita, D. Fujishima, A. Yano, A. Ogane, S. Tohoda, K. Matsuyama, Y. Nakamura, N. Tokuoka, H. Kanno, H. Sakata, M. Taguchi, and E. Maruyama, in 26th European Photovoltaic Solar Energy Conference and Exhibition (Hamburg, Germany, 2011), p. 871.

${ }^{6}$ A. Cuevas, IEEE J. Photovolt. 3, 916 (2013).

${ }^{7}$ P. Würfel, Physics of Solar Cells (Wiley-VCH, 2008).

${ }^{8}$ J.-H. Choi, S.-K. Kim, J.-C. Lee, H. Park, W.-J. Lee, and E.-C. Cho, in 26th European Photovoltaic Solar Energy Conference and Exhibition (Hamburg, Germany, 2011), p. 3302.

${ }^{9}$ A. Descoeudres, Z. C. Holman, L. Barraud, S. Morel, S. De Wolf, and C. Ballif, IEEE J. Photovolt. 3, 83 (2013).

${ }^{10}$ S. Martín de Nicolás, D. Muñoz, A. S. Ozanne, N. Nguyen, and P. J. Ribeyron, Energy Procedia 8, 226 (2011).

${ }^{11}$ M. Tanaka, M. Taguchi, T. Matsuyama, T. Sawada, S. Tsuda, S. Nakano, H. Hanafusa, and Y. Kuwano, Jpn. J. Appl. Phys., Part 1 31, 3518 (1992).

${ }^{12}$ H. Fujiwara and M. Kondo, J. Appl. Phys. 101, 054516 (2007).

${ }^{13}$ N. Jensen, R. M. Hausner, R. B. Bergmann, J. H. Werner, and U. Rau, Prog. Photovoltaics Res. Appl. 10, 1 (2002).

${ }^{14}$ D. Pysch, C. Meinhard, N.-P. Harder, M. Hermle, and S. W. Glunz, J. Appl. Phys. 110, 094516 (2011).

${ }^{15}$ Z. C. Holman, A. Descoeudres, L. Barraud, F. Zicarelli Fernandez, J. P. Seif, S. De Wolf, and C. Ballif, IEEE J. Photovolt. 2, 7 (2012).

${ }^{16}$ P. Cuony, M. Marending, D. T. L. Alexander, M. Boccard, G. Bugnon, M. Despeisse, and C. Ballif, Appl. Phys. Lett. 97, 213502 (2010).

${ }^{17}$ A. Lambertz, T. Grundler, and F. Finger, J. Appl. Phys. 109, 113109 (2011).

${ }^{18}$ K. Ding, U. Aeberhard, F. Finger, and U. Rau, Phys. Status Solidi (RRL) 6, 193 (2012)

${ }^{19}$ K. Ding, U. Aeberhard, F. Finger, and U. Rau, J. Appl. Phys. 113, 134501 (2013).

${ }^{20}$ F. Einsele, W. Beyer, and U. Rau, J. Appl. Phys. 112, 054905 (2012).

${ }^{21}$ T. Mueller, S. Schwertheim, and W. R. Fahrner, J. Appl. Phys. 107, 014504 (2010).

${ }^{22}$ A. Janotta, R. Janssen, M. Schmidt, T. Graf, M. Stutzmann, L. Görgens, A. Bergmaier, G. Dollinger, C. Hammerl, S. Schreiber, and B. Stritzker, Phys. Rev. B 69, 115206 (2004).

${ }^{23}$ R. A. Sinton and A. Cuevas, Appl. Phys. Lett. 69, 2510 (1996).

${ }^{24}$ B. Demaurex, S. De Wolf, A. Descoeudres, Z. C. Holman, and C. Ballif, Appl. Phys. Lett. 101, 171604 (2012).

${ }^{25}$ F. Zicarelli, A. Descoeudres, G. Choong, P. Bôle, L. Barraud, S. De Wolf, and C. Ballif, in 25th European Photovoltaic Solar Energy Conference and Exhibition (Valencia, Spain, 2010), p. 1669.

${ }^{26}$ R. A. Sinton and A. Cuevas, in 16th European Photovoltaic Solar Energy Conference (Glasgow, UK, 2000), p. 1.

${ }^{27}$ S. De Wolf and M. Kondo, Appl. Phys. Lett. 91, 112109 (2007).

${ }^{28}$ L.-N. He, D.-M. Wang, and S. Hasegawa, J. Non-Cryst. Solids 261, 67 (2000).
${ }^{29}$ D. Jousse, E. Bustarret, and F. Boulitrop, Solid State Commun. 55, 435 (1985).

${ }^{30}$ S. De Wolf, S. Olibet, and C. Ballif, Appl. Phys. Lett. 93, 032101 (2008).

${ }^{31}$ W. Beyer, Physica B 170, 105 (1991).

${ }^{32}$ P. Gupta, V. L. Colvin, and S. M. George, Phys. Rev. B 37, 8234 (1988).

${ }^{33}$ M. Cardona, Phys. Status Solidi B 118, 463 (1983).

${ }^{34}$ H. Wagner and W. Beyer, Solid State Commun. 48, 585 (1983).

${ }^{35}$ T. F. Schulze, H. N. Beushausen, C. Leendertz, A. Dobrich, B. Rech, and L. Korte, Appl. Phys. Lett. 96, 252102 (2010).

${ }^{36}$ L. Zhao, H. Diao, X. Zeng, C. Zhou, H. Li, and W. Wang, Physica B 405, 61 (2010).

${ }^{37}$ J. C. Knights, R. A. Street, and G. Lucovsky, J. Non-Cryst. Solids 35 \& 36, 279 (1980).

${ }^{38}$ P. Cuony, D. T. L. Alexander, I. Perez-Wurfl, M. Despeisse, G. Bugnon, M. Boccard, T. Soderstrom, A. Hessler-Wyser, C. Hebert, and C. Ballif, Adv. Mater. 24, 1182 (2012).

${ }^{39}$ S. M. Iftiquar, J. Phys. D: Appl. Phys. 31, 1630 (1998).

${ }^{40}$ S. Kageyama, M. Akagawa, and H. Fujiwara, Phys. Rev. B 83, 195205 (2011).

${ }^{41}$ T. F. Schulze, L. Korte, F. Ruske, and B. Rech, Phys. Rev. B 83, 165314 (2011)

${ }^{42}$ A. H. M. Smets, M. A. Wank, B. Vet, M. Fischer, R. A. C. M. M. van Swaaij, M. Zeman, D. C. Bobela, C. R. Wronski, and R. M. C. M. van de Sanden, IEEE J. Photovolt. 2, 94 (2012).

${ }^{43}$ J. Geissbuühler, S. De Wolf, B. Demaurex, J. P. Seif, D. T. L. Alexander, L. Barraud, and C. Ballif, Appl. Phys. Lett. 102, 231604 (2013).

${ }^{44}$ M. Niwano, J.-i. Kageyama, K. Kinashi, N. Miyamoto, and K. Honma, J. Vac. Sci. Technol., A 12, 465 (1994).

${ }^{45}$ A. Bacioğlu, A. O. Kodolbaş, and Ö. Öktü, Sol. Energy Mater. Sol. Cells 89, 49 (2005).

${ }^{46}$ S. C. Baker-Finch and K. R. McIntosh, in 35th IEEE Photovoltaic Specialists Conference (Honolulu, HI, USA, 2010), p. 002184.

${ }^{47}$ The deviation from the predicted value of $0.81 \mathrm{~mA} / \mathrm{cm}^{2}$, for both $J-V$ and $E Q E$ measurements can be explained by a spectral mismatch of the three different spectra used for simulation and the two measurements.

${ }^{48}$ T. Tiedje, E. Yablonovitch, G. D. Cody, and B. G. Brooks, IEEE Trans. Electron Devices ED-31, 711 (1984).

${ }^{49}$ Z. Shu, U. Das, J. Allen, R. Birkmire, and S. Hegedus, Prog. Photovoltaics (2013).

${ }^{50}$ M. W. M. Van Cleef, F. A. Rubinelli, R. Rizzoli, and R. Pinghini, Jpn. J. Appl. Phys., Part 1 37, 3926 (1998).

${ }^{51}$ M. Rahmouni, A. Datta, P. Chatterjee, J. Damon-Lacoste, C. Ballif, and P. Roca i Cabarrocas, J. Appl. Phys. 107, 054521 (2010).

${ }^{52}$ D. A. Clugston and P. A. Basore, in 26th IEEE Photovoltaic Specialists Conference (Anaheim, CA, USA, 1997), p. 207.

${ }^{53}$ J. Krč, F. Smole, and M. Topič, Prog. Photovoltaics Res. Appl. 11, 15 (2003).

${ }^{54}$ M. Nerat, G. Cernivec, F. Smole, and M. Topič, in 24th European Photovoltaic Solar Energy Conference (Hamburg, Germany, 2009), p. 2433.

${ }^{55}$ Z. C. Holman, M. Filipič, A. Descoeudres, S. De Wolf, F. Smole, M. Topič, and C. Ballif, J. Appl. Phys. 113, 013107 (2013).

${ }^{56} \mathrm{M}$. Lu, U. Das, S. Bowden, S. Hegedus, and R. Birkmire, Prog. Photovoltaics Res. Appl. 19, 326 (2011).

${ }^{57}$ M. Filipič, Z. C. Holman, F. Smole, S. De Wolf, C. Ballif, and M. Topič, J. Appl. Phys. 114, 074504 (2013).

${ }^{58}$ R. L. Anderson, Appl. Phys. Lett. 27, 691 (1975).

${ }^{59}$ M. Taguchi, E. Maruyama, and M. Tanaka, Jpn. J. Appl. Phys., Part 147 , 814 (2008). 